\title{
Jewish studies in the Nordic countries today
}

\author{
EDITORIAL
}

The current volume of Scripta Instituti Donneriani Aboensis is based on a symposium arranged
by the Donner Institute in March 2015, holding the title Jewish studies in the Nordic Countries
Today.

Jewish studies have for centuries formed a central part of the academic work within faculties of theology and the humanities in the Nordic countries. Research relating to Judaism has been conducted from a broad spectrum of theoretical perspectives, ranging from historical and exegetic approaches to cultural and linguistic studies as well as ethnographic investigations spanning diverse cultural and geographic areas, time periods and communities. The field is thoroughly interdisciplinary, combining methodologies from the humanities, theology and the social sciences.

The contacts between Nordic scholars in the field have always been an important source of academic exchange, debate and learning. Nourishing these networks is vital both for individual researchers in the field and for the professionalization of the academic discipline as such at our Nordic universities. By organising this seminar and publishing this volume, the Donner Institute wishes to contribute to the strengthening of the Nordic conversation on Jewish studies. We are pleased to be able to publish this volume, containing articles by several prominent Nordic scholars in the field, dealing with current approaches, findings and challenges within their own research, thus contributing to a lively and creative scholarly discussion where different theoretical, methodological and epistemological perspectives can meet.

The volume opens with four historically oriented articles dealing with classical source texts and their interpretation. Cecilia Wassen discusses Jesus' relation to questions of ritual purity and, contrary to most scholars in the field, argues for the conclusion that Jesus was far from disinterested in such matters. Karin Hedner Zetterholm, for her part, analyses Jesus-oriented visions of Judaism in antiquity as they are presented in three third- and fourth-century texts. Antti Laato traces early apologies for the virgin birth of Jesus in the Jewish Toledot 


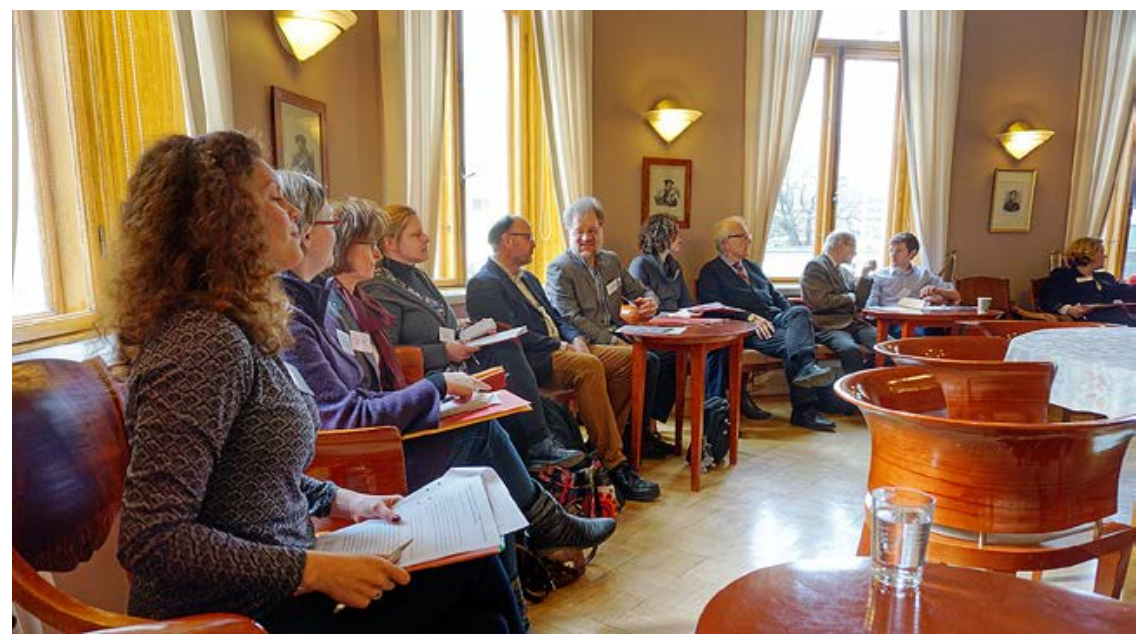

Participants in the symposium 'Jewish Studies in the Nordic Countries Today' gathered at Åbo Akademi University in March, 2015. Photo by Björn Dahla.

Yeshu tradition. Early modern Polish-Lithuanian Karaite poems are the subject of Riikka Tuori's article, focusing on poems written on the biblical narrative of the binding of Isaac.

The following section deals with more recent historical themes relating to Judaism in the Nordic countries. Claudia Welz offers a phenomenological, psychological and ethical analysis of Holocaust testimonies and the crisis of witnessing constituted by the Shoah. Jewish Holocaust survivors are the theme also of Sofie Lene Bak's article, dealing with the repatriation and restitution of Holocaust victims in post-war Denmark. In Vibeke Kieding Banik's article, the discussion moves on to Norway and the perceived crisis of identity among the local Jewry that was vividly debated in the interwar period. Laura Ekholm and Simo Muir, on their part, analyse the organized name-change process in the r 930 in the Jewish Community of Helsinki, presenting the often rather innovative results of these processes. Jan Schwarz offers a reassessment of the state of Yiddish language and culture in Europe in the decades following the Holocaust, concluding that they were indeed in dynamic flux. The section closes with Christhard Hoffmann's critical overview of the historiography on Jewish immigration and integration in Sweden, Denmark and Norway.

After this, focus is broadened towards questions of a more general philosophical and theological nature. Risto Nurmela reviews Sigmund Freud's last work Moses and Monotheism, and the portrayal of Moses given in this book. Mia Anderssén-Löf, on her part, studies the understanding of redemption and 
particularly the role of the Messiah to redemption as expressed in Haredi and Hardal Jewish writings. Finally, two ethnographically driven articles focusing on contemporary Jewry are presented. Ben Kasstan's reflexive analysis of his own fieldwork among the Haredi community in Manchester brings a methodological contribution to the volume. The recreation of traditional Hasidic song practices among progressive Jews in London is the topic of Ruth Illman's article, which illuminates the phenomenon in relation to theories of contemporary religious change. The volume is concluded by Natalie Lantz, who offers a personal reflection on what it means to pursue Jewish studies in Sweden, discussing the obstacles and opportunities that rise to the fore from a student's point of view.

We are grateful to all authors for their dedicated work with this volume and to the reviewers, who with their professional and engaged comments have contributed to the crystallization of this volume into a publication of notable academic standard. We hope that it will be valuable and stimulating for students and researchers within the various fields in which issues relating to Jews and Judaism in the Nordic countries arise.

Turku/Åbo 29 January 2016, Ruth Illman and Björn Dabla 
